\title{
Research on Correlation of Perceptual Learning Style, Learning Strategy and College English Proficiency
}

\author{
Liu jingfei \\ Wuhan University of Science and Technology, Wuhan, Hubei, China \\ jingfei8@163.com
}

Keywords: perceptual learning style, learning strategy, English proficiency

\begin{abstract}
The aim of the research is to investigate if perceptual learning style and learning strategy has correlation with English learning achievement. The writer tries surveying the overall learning style tendency and overall learning strategy application tendency of students, and analyzes the correlation of different learning style, learning strategy and English learning proficiency. For the problems, the research proposes three hypotheses. The data indicates that the most popular learning style is visual learning style. And the next is tactile learning style and learning and listening learning style. The research results indicate that the students often use compensation strategy, cognitive strategy, metacognitive strategy and social strategy, and seldom use affective strategy. The variables of learning style and learning strategy are the important factors of influencing the achievement of English learners.
\end{abstract}

\section{Introduction}

The research about learning style dated back to the 1970s. Learning style theory means to summarize how the individuals learn under different learning conditions. It is the research on individual difference, and the researchers originally wanted to explore individual difference and performance difference. The research of learning strategy began in the 1970s. The development of cognitive psychology influences learning strategy research. According to the theory of modern cognitive psychology, learning is a complicated process of thinking and solving problems. O'malley \& Chamot (1990) thought that learning the second language is a complicated cognitive skill. Learners not only need to accept, understand and comprehend the external world, but also must effectively use mental process such as thinking, selection, memory, recognition and classification. Under the guidance of cognitive psychology, the emphasis of researching learning is changing into inner thought and learning process.

\section{Research Design and Implementation}

Target and hypothesis. In order to deeply research the English learning style and learning strategy of the student, the research proposes some suggestions, for improving teaching and learning efficiency of teachers and students.

Based on referring to the past references and actual investigations, the writer proposes the following hypotheses.

Hypothesis 1: Visual learning style, learning strategy and student achievement has close relationship.

Hypothesis 2: Auditory learning style, learning strategy and student achievement has close relationship.

Hypothesis 3: Tactile learning style, learning strategy and student achievement has close relationship.

Sample selection and tools. The research relates to 100 students in a middle school, and the students are selected from the second grade of Junior middle school in four different schools. The reason why the Second-year junior high school students are selected is that they have entered the school for about one year, and they have adapted to the middle school life and formed their own 
learning styles. And they have their own learning style and learning strategy.

The research tools in the paper are learning perceptual style preference investigation and language learning strategy scale, and English learning achievement selects the final examination results of the students.

PLSPS measures the perceptual learning style preference by investigations, and was designed by Reid' s in 1984. The students have many learning ways, for example, some students like to use their eyes, and some students love to learn according to experience. The tool can help the students to find out the best learning style.

Language learning strategy scale. SILL aims at self-investigation of English learners, and was firstly designed by Oxford (1990). SILL includes six learning strategies, memory strategy, cognitive strategy, compensation strategy, meta-cognitive strategy, affective strategy and social strategy. In the research, it includes five parts.

(1) Problem 1-6: cognitive strategy is used from comprehending and generation language.

(2) Problem 7-12: compensation strategy is used for overcoming the defects of other available information learning languages.

(3) Problem 13-18: meta-cognitive strategy is used for adjusting the emotion, motivation and attitude of students.

(4) Problem 25-30 is used to improve the interaction of learning and others.

\section{Data Collection and Analysis of Empirical Results}

Data set. 100 students are selected. After investigation, 9 effective questionnaires are recycled. For 96 students, there are 55 boys and 41 girls.

PLSPS and SILL data of participants is achieved by questionnaires. The test scores are provided their teachers.

Result analysis. 1) Reliability of questionnaires

Trough objective analysis on reliability of questionnaires, the paper gets the following results.

Table 1 Data reliability analysis (alpha)

\begin{tabular}{|l|l|l|l|}
\hline \multirow{2}{*}{} & \multicolumn{3}{|c|}{ Credibility } \\
\cline { 2 - 4 } & Samples & Problems & Alpha score \\
\hline Perceptual learning style & 96.0 & 24 & 0.7739 \\
\hline Learning strategy & 96.0 & 30 & 0.8686 \\
\hline
\end{tabular}

From the above table, we can see that the alpha score of perceptual learning style is 0.7739 , and that of learning strategy is 0.8686 . So the reliability of the questionnaires is high, and they can be used for the research.

2) General tendency of perceptual learning style preference. According to the response of the students in the questionnaires, the survey results of perceptual learning style preference receives SPSS calculation, and the results are as follows.

Table 2 Mean of perceptual learning style preference

\begin{tabular}{|l|l|l|l|l|l|}
\hline Style & Minimum & Maximum & Mean & $\begin{array}{l}\text { Standard } \\
\text { deviation }\end{array}$ & Rank \\
\hline Visual (1-8) & 1.00 & 5.00 & 3.4284 & 1.05770 & 1 \\
\hline $\begin{array}{l}\text { Auditory } \\
(9-16)\end{array}$ & 1.00 & 5.00 & 3.0677 & 1.03931 & 3 \\
\hline $\begin{array}{l}\text { Tactile } \\
(17-24)\end{array}$ & 1.00 & 5.00 & 3.3841 & 1.14165 & 2 \\
\hline
\end{tabular}

From the above table, we can see that the most popular learning style is visual style (3.4284), and the next is tactile learning style (3.3841) and auditory learning style (3.0677). The difference 
between visual learning style and tactile learning style is 0.0443 , and that of auditory learning style and tactile learning style is 0.3164 .

The teaching style of teachers also influences the learning style preference of students, so there is the research about teaching styles of teachers.

Table 3 Teaching style of teachers

\begin{tabular}{|l|l|l|l|l|}
\hline & Minimum & Maximum & Mean & $\begin{array}{l}\text { Standard } \\
\text { deviation }\end{array}$ \\
\hline VT & 1.00 & 5.00 & 3.2854 & 1.08878 \\
\hline AT & 1.00 & 5.00 & 3.4479 & 1.03462 \\
\hline HT & 1.00 & 5.00 & 3.3854 & 1.18970 \\
\hline
\end{tabular}

Note: VT, visual teaching style, AT: auditory teaching style, HT: tactile teaching style. Through the comparison, it is easy for us to notice difference perceptual learning style preferences between teachers and students. The most popular teaching style for teachers is auditory teaching style, but the best learning style for students is visual learning style.

\section{General tendency of learning strategy application}

The learning strategy application condition of students is computed, and the results are shown in the following table.

Table 4 Statistical analysis on learning strategy selection of students

\begin{tabular}{|l|l|l|l|l|}
\hline Strategy & Minimum & Maximum & Mean & $\begin{array}{l}\text { Standard } \\
\text { deviation }\end{array}$ \\
\hline $\begin{array}{l}\text { Cognitive strategy } \\
(1-6)\end{array}$ & 1.00 & 5.00 & 3.4201 & 1.07001 \\
\hline $\begin{array}{l}\text { Compensation } \\
\text { strategy (7-12) }\end{array}$ & 1.00 & 5.00 & 3.5191 & 1.05319 \\
\hline $\begin{array}{l}\text { Meta-cognitive } \\
\text { strategy (13-18) }\end{array}$ & 1.00 & 5.00 & 3.3073 & 1.03723 \\
\hline $\begin{array}{l}\text { Affective strategy } \\
(19-24)\end{array}$ & 1.00 & 5.00 & 2.9861 & 1.15110 \\
\hline $\begin{array}{l}\text { Social strategy } \\
(25-30)\end{array}$ & 1.00 & 5.00 & 3.2274 & 1.12304 \\
\hline
\end{tabular}

From the above table, we can see that the compensation strategy (3.5191) and cognition strategy (3.4201) is the most popular, meta-cognition strategy (3.3073) and social strategy (3.2274) is secondary, and affective strategy (2.9861) is the last.

Perceptual learning style. In order to find the perceptual learning style factors of influencing English achievement of students, the students are classified according to their perceptual learning style preference. Each student answer 24 problems in PLSPS questionnaire which relates to three perceptual learning styles. The previous eight items are about visual learning style preference, and the following eight items are about auditory learning style preference. And other problems are about tactile learning style preference. In order to make calculation easy, the scores of eight problems in each preference are aggregated to get three groups of scores, so each student has three scores. The learning style of students is judged by scores, and the results are as follows.

Table 5 Distribution of students with different learning styles

\begin{tabular}{|l|l|l|}
\hline Style & Number & Percentage \\
\hline Visual & 22 & $22.92 \%$ \\
\hline Auditory & 18 & $18.75 \%$ \\
\hline Tactile & 36 & $37.50 \%$ \\
\hline Other & 20 & $20.83 \%$ \\
\hline
\end{tabular}


The examination results of students are analyzed, which includes total score, listening score, reading score, vocabulary score and writing score. The scores of students with different learning styles are as follows.

Table 6 Average score of students with different perceptual learning styles

\begin{tabular}{|l|l|l|l|l|l|}
\hline Style & Total score & Listening & Reading & Vocabulary & Writing \\
\hline Auditory & 72.676 & 18.66317 & 14.34803 & 8.147415 & $\begin{array}{l}31.1853 \\
2\end{array}$ \\
\hline Tactile & 70.45505 & 18.76366 & 12.83385 & 7.625367 & $\begin{array}{l}31.2321 \\
7\end{array}$ \\
\hline Other & 70.02414 & 17.74726 & 12.96032 & 8.131227 & $\begin{array}{l}31.5166 \\
1\end{array}$ \\
\hline
\end{tabular}

From the above table, we can see that the score of the students with visual learning style preference is better. The total score is (72.676), in which the reading score (14.34803) and the vocabulary score $(8.147415)$ is the highest. The highest listening score of the students with the auditory learning strategy preference is 18.76366 . The writing score (31.51661) of the students with the tactile learning strategy preference is the best. The average score of the students with visual style is the highest, which is higher than the other styles. For listening score, the students of visual style and auditory style are better than that of tactile style. For reading score, the average score of the students with auditory and tactile style is close, and is lower than the students with visual style. For vocabulary score, the average score of the students with visual and tactile style is nearly the same, which is higher than the students with auditory style.

Learning strategy application of students with different perceptual learning styles. The students have been classified according perceptual learning style preference. The chapter describes the learning strategy application of students with different perceptual learning styles.

Table 7 Learning strategy application of students with different perceptual learning styles

\begin{tabular}{|c|c|c|c|c|c|c|}
\hline & & $\begin{array}{l}\text { Cognition } \\
\text { strategy }\end{array}$ & $\begin{array}{l}\text { Compensation } \\
\text { strategy }\end{array}$ & $\begin{array}{l}\text { Meta-cognitio } \\
\text { n strategy }\end{array}$ & $\begin{array}{l}\text { Affectiv } \\
\text { e } \\
\text { strategy }\end{array}$ & $\begin{array}{l}\text { Social } \\
\text { strategy }\end{array}$ \\
\hline Visual & Score & 3.4091 & 3.5152 & 3.3636 & 3.0076 & 3.3864 \\
\hline Auditory & Score & 3.3981 & 3.6018 & 3.0833 & 2.8981 & 3.1111 \\
\hline Tactile & Score & 3.4907 & 3.5972 & 3.4259 & 3.0463 & 3.3472 \\
\hline
\end{tabular}

From the above table, we can see that the score of the compensation strategy is the highest in three groups $(3.5152,3.60183,3.5972)$, and the score of affective strategy is the lowest $(3.0076,2.8981$, 3.0463. The result meets the general tendency of learning strategy use, which proves that compensation strategy is popular, and affective strategy attracts the least attention.

\section{Conclusions}

From the above analysis, the paper draws the following conclusions.

For the students with visual learning style, visual learning style has important relationship with compensation strategy, affective strategy, total score and reading score. Cognitive strategy has close relationship with vocabulary score. There is important relationship between compensation strategy and total score, listening score and reading score. Meta-cognitive strategy and reading score has close relationship, so is the emotional strategy and reading score.

For auditory learners, there is important relationship between auditory learning style and meta-cognitive strategy, social strategy, listening score and vocabulary score. Cognition strategy has close relationship with vocabulary score. Compensation strategy has important relationship with 
listening score and writing score. Meta-cognition strategy has close relationship with listening score, so does the social learning strategy and listening score.

For tactile learners, cognition strategy has important relationship with tactile learning style and reading score. Compensation strategy has close relationship with tactile learning style and writing score. There is significant relationship between meta-cognitive strategy and reading score and writing score of social strategy.

The research investigates the perceptual learning style, application of learning strategy of students and the relevant achievements, but the research achievements need to be perfected in the further research.

\section{References}

[1] Coffield, F. et al, Learning styles and pedagogy in post-16 learning. Learning and Skills Research Center, www.LSRC.AC.UK, 2004.

[2] Liu Ping, Investigation on learning style of non-English-major college students, Sino-American English Teaching, 2005(2): 35-38.

[3] Cheng Xiaotang, Zheng Min, English learning strategy, Beijing: Foreign Language Teaching and Research Press, 2002.

[4] Li Li, Chen Zhi'an, Jiang Yuhong, Strategy·style·attribution - learning how to study English, Shanghai: Shanghai Foreign Language Education Press, 2006. 